\title{
Sweating Effect on Males and Females Body Temperature Variation
}

\section{Gurung DB and Acharya S $^{*}$}

Department of Natural Sciences (Mathematics), Kathmandu University, Kathmandu, Nepal, India

\begin{abstract}
The human bodies have to stay their normal temperature because the enzymes that causes reaction in the body functions are best at normal temperature. The study deals comparative study of thermoregulation activities of human males and females under hot zone due to sweating. The solution is presented on the basis of variational finite element method for one and two dimensional steady and transient cases. Sweating is one of the effective thermoregulatory processes when the body is in hot condition of heat strain caused by hot ambient conditions or a high metabolic rate. Sweating is considered as a loss of heat from the body by evaporation of water inside body. The sweating rate for male is calculated by the relation;

$\mathrm{E}=8.47 \times 10-5\left(0.1 \times \mathrm{T}_{\mathrm{sk}}+0.9 \times \mathrm{Tb}\right)-36.6\left[\mathrm{~kg} / \mathrm{m}^{2} / \mathrm{sec}\right]$

where, Tsk=T0 (Outer skin surface temperature), $\mathrm{Tb}=37$ (Body core temperature). The rate of sweating in females is less compared to males due to the lower density of sweat gland and hormonal pattern in females. So, coefficient of $\mathrm{Tb}$ is considered as 0.7 instead of 0.9 in above relation for females. The analysis sought out that tissue temperature in males is slightly higher as compared to females when atmospheric temperature To is less than body core temperature. But the females tissue temperature is higher when $\mathrm{T}^{\infty}$ exceeds above $37^{\circ} \mathrm{C}$. The steady state nodal temperature is achieved earlier in case of males in comparison to females.
\end{abstract}

Keywords: Thermoregulation; Finite element method; Sweating

\section{Background}

Skin plays a particular role in regulating heat by the controlling of perspiration (evaporative cooling) and blood flow to the skin. Skin temperature is one of the major factors determining heat exchange with the environment. It provides the thermoregulatory system with important information about need to conserve or dissipate heat [1]. The human body is a complex structure where the balance of mass and heat transport in all tissue is necessary for its normal functioning [2]. Physiological temperature regulation is controlled by rate of metabolic heat production, perfusion and sweating [3]. Evaporative heat exchange involves the loss of latent heat through the evaporation of sweat from the skin surface [4]. Heat loss via evaporative heat exchange depends upon the combined effects of skin and internal body temperature on the sweating drive and the ability of sweat to evaporate from the skin surface [5-8].

Heat loss mechanisms protect the body from excessively high temperatures [9]. Most heat loss occurs through the skin via the physical mechanisms of the heat exchange, such as radiation, conduction, convection, and evaporation [10]. Heat loss by radiation and convection alone are unable to maintain adequate temperature homeostasis at high environmental temperatures or during strenuous physical activity [11-13]. When core temperature rises above normal temperature the hypothalamic heat producing center is inhibited and at the same time heat loss center is activated and heat lost by evaporation. At ambient temperatures above $36^{\circ} \mathrm{C}$ or so, heat loss occurs by evaporation only [14-18].

As atmospheric temperature increases, sweat glands are activated to compound the cooling effects of peripheral vasodilation (convective heat loss) [19]. Apocrine and eccrine glands secrete sweat onto the skin surface which caused evaporative cooling when it is converted from liquid to water vapour [20].

Generally, sweat rate in males are higher than in females [21]. The physical parameter associate with lower sweat rate in females are body mass and surface area. The body mass represent the capacity of the body to store heat. The amount of body surface area exposed to the external environment determine the heat exchange between the skin and ambient temperature such as larger body surface area to body mass generally associated with higher skin temperature.

In general females have less body surface area to body mass compared to males. Larger surface areas allow more molecules to leave the liquid than smaller one, and therefore sweat occurs more rapidly. Metabolic energy expenditure is proportional to body mass. Lower rate of metabolic heat production elicit a lower sweat rate in females. The physiological parameter associate with lower sweat rate in females is due to less thermal sensitivity of the response because females have less active sweat glands as compared to males.

Wyndham et al. [4] studied that lower sweat production of females compared to males under equivalent heat stress result of females sex hormones.

Nadel et al. [3] conducted a study on the importance of skin temperature in the regulation of sweating. They concluded that at a constant skin temperature, sweating rate was proportional to core temperature. At a constant core temperature, sweating rate was proportional to skin temperature, and at a given combination of core and mean skin temperatures, local sweating was dependent on the local skin temperature.

*Corresponding author: Acharya S, Department of Natural Sciences (Mathematics), Kathmandu University, Kathmandu, Nepal, India ,Tel: 977 11663734; E-mail: saraswati.acharya@ku.edu.np

Received April 10, 2018; Accepted April 12, 2018; Published May 09, 2018

Citation: Gurung DB, Acharya S (2018) Sweating Effect on Males and Females Body Temperature Variation. J Appl Computat Math 7: 401. doi: 10.4172/21689679.1000401

Copyright: @ 2018 Gurung DB, et al. This is an open-access article distributed under the terms of the Creative Commons Attribution License, which permits unrestricted use, distribution, and reproduction in any medium, provided the original author and source are credited. 
Citation: Gurung DB, Acharya S (2018) Sweating Effect on Males and Females Body Temperature Variation. J Appl Computat Math 7: 401. doi: 10.4172/2168-9679.1000401

Page 2 of 11

Lot of research has been carried out to deal with the thermoregulation of males body but very few studies with females. So, study focuses on mathematical model of the body temperatures in males and females due to sweating responses for thermal sensitivity.

\section{Model Formulation}

\section{Governing equation}

The governing differential equation representing the bio-heat transfer in the human skin can be written by the well-known Pennes eqn. [15] addressing the effect of conduction, blood perfusion and metabolism is given by:

$$
\rho c \frac{\partial T}{\partial t}=\nabla \cdot(K \nabla T)+\omega_{b} \rho_{b} c_{p}\left(T_{a}-T\right)+q_{m}
$$

Where,

Notation
$\rho b$
$\mathrm{cb}$
$\mathrm{K}$
$\omega \mathrm{b}$
$\mathrm{Ta}$
$\mathrm{T}$
$\mathrm{qm}$

Unit

$\mathrm{Kg} / \mathrm{m}^{3}$

$\mathrm{J} / \mathrm{kg} /{ }^{\circ} \mathrm{C}$

$\mathrm{w} / \mathrm{m} /{ }^{\circ} \mathrm{C}$

$\mathrm{s}^{-1}$

${ }^{\circ} \mathrm{C}$

${ }^{\circ} \mathrm{C}$

$w / \mathrm{m}^{3}$

\section{Discretization}

In this study, thickness of skin layers has been measured perpendicularly from the outer skin surface towards the body core. As well, thickness of fatty part of female's subcutaneous tissue is considered slightly thicker as compared with males due to greater amount of subcutaneous fat of females. The schematic diagrams 1 and 2 of human SST regions are discretized to visualize the skin layers for modeming on temperature distribution.

For one dimensional modelling, a schematic diagram of the human skin layers (Figure 1) is divided into six regions. The thickness of stratum corneum, stratum germinativum, papillary region, reticular region, fatty and muscle parts of subcutaneous tissue have been considered as $\mathrm{l}_{1}, \mathrm{l}_{2}-\mathrm{l}_{1}, \mathrm{l}_{3}-\mathrm{l}_{2}, \mathrm{l}_{4}-\mathrm{l}_{3}, \mathrm{l}_{5}-\mathrm{l}_{4}$ and $\mathrm{l}_{6}-\mathrm{l}_{5}$ respectively and $\mathrm{T}_{0}$, $\mathrm{T}_{1}, \mathrm{~T}_{2}, \mathrm{~T}_{3}, \mathrm{~T}_{4}$ and $\mathrm{T}_{5}$ are the nodal temperatures at a distances $\mathrm{x}=0, \mathrm{x}=\mathrm{l}_{1}$, $\mathrm{x}=\mathrm{l}_{2}, \mathrm{x}=\mathrm{l}_{3}, \mathrm{x}=\mathrm{l}_{4}, \mathrm{x}=\mathrm{l}_{5}$ and $\mathrm{x}=\mathrm{l}_{6}$ respectively. $\mathrm{T}(\mathrm{i})$ where $\mathrm{i}=1,2,3,4,5,6$ be the temperature function in the layers stratum corneum, stratum germinativum, papillary region, reticular region, fatty and muscle parts of subcutaneous tissue respectively. Similarly, $\mathrm{T}_{0}=\mathrm{T}_{\mathrm{b}}$ is the body core temperature at $\mathrm{x}=\mathrm{l}_{6}[1]$.

In the two dimensional modeling, the skin thickness has been considered as two dimensional rectangular skin and subcutaneous tissue region (Figure 2). The thickness of skin along $\mathrm{X}$-axis is $0.50 \mathrm{~cm}$. The thickness along vertical axis (y-axis) is $0.90 \mathrm{~cm}$ for males and $1 \mathrm{~cm}$

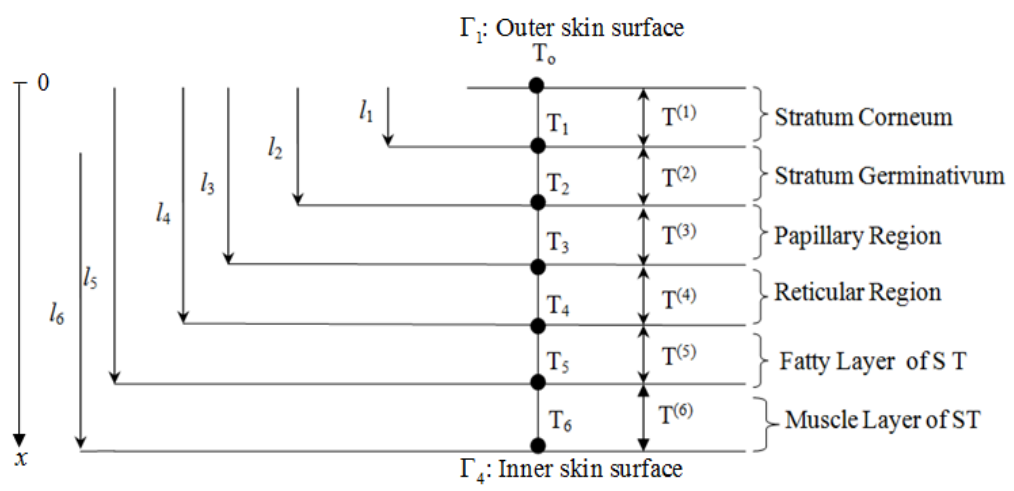

Figure 1: Schematic diagram of one dimensional human skin layers.

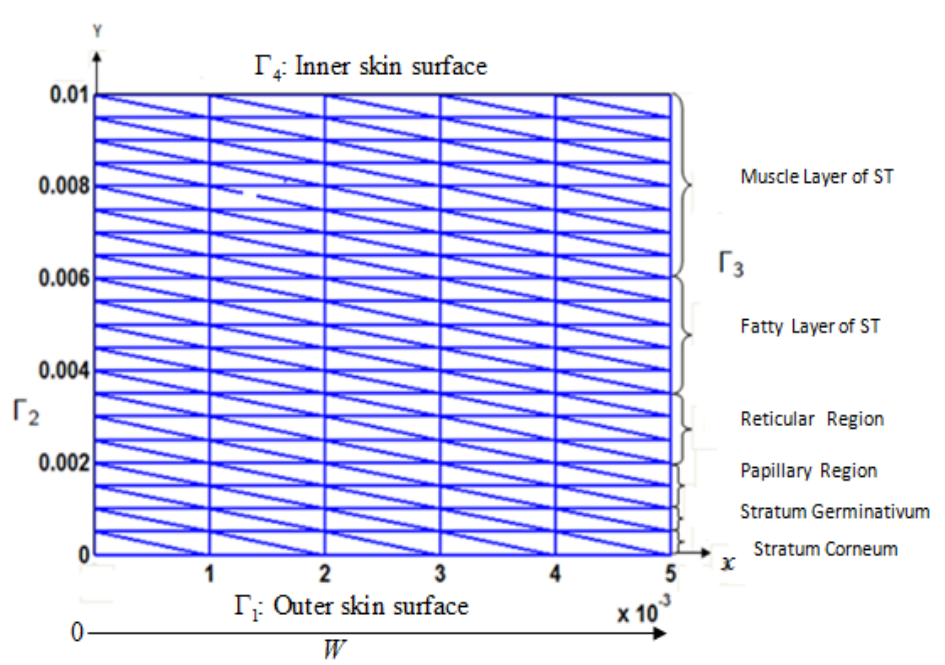

Figure 2: Schematic diagram of two dimensional human skin layers 
for females due to their different subcutaneous fat thickness. Initially, the skin is divided into 180 nodal elements with triangular shape having total 114 nodes for males and 200 nodal elements with triangular shape having total 126 nodes for females. The stratum corneum, stratum germinativum, papillary region, reticular region and fatty and muscles layers of subcutaneous tissue are divided into $10,10,20,30,40$, and 70 triangular elements for males and 10,10,20,30,50, and 80 triangular elements for females as shown in Figure 2 [20].

\section{Boundary conditions}

The mixed boundary condition of heat flux from outer skin surface under one dimensional study is taken as in eqns. (2) and (6). In two dimensional discretization of the dermal layers, thicknesses has been taken along y-axis and the loss of heat from the outer surface of the body is exposed to the environment then the heat loss caused via convection, radiation and sweat evaporation. So the mixed boundary condition of heat flux from outer skin surface under study is given by:

$$
\begin{aligned}
& \Gamma_{\text {skin surface }}:-\left.k \frac{\partial T}{\partial \eta}\right|_{\text {at skin surface }}=h_{\text {conv }}\left(T(0, t)-T_{\infty}\right)+\sigma \varepsilon\left(T^{4}(0, \mathrm{t})-\mathrm{T}_{\infty}^{4}\right)+L E_{\text {male }} \\
& \Gamma_{\text {skin surface }}:-\left.k \frac{\partial T}{\partial \eta}\right|_{\text {at skin surface }}=h_{\text {conv }}\left(T(0, t)-T_{\infty}\right)+\sigma \varepsilon\left(T^{4}(0, \mathrm{t})-\mathrm{T}_{\infty}^{4}\right)+L E_{\text {female }}
\end{aligned}
$$

where [18],

$$
\begin{aligned}
& \mathrm{E}_{\text {male }=} 8.47 \times 10^{-5}\left(0.1 \times \mathrm{T}_{0}+0.9 \times \mathrm{T}_{\mathrm{b}}\right)-36.6^{\circ} \mathrm{C} \\
& \mathrm{E}_{\text {female }}=8.47 \times 10^{-5}\left(0.1 \times \mathrm{T}_{0}+0.7 \times \mathrm{T}_{\mathrm{b}}\right)-36.6^{\circ} \mathrm{C}
\end{aligned}
$$

Where

$$
\begin{array}{cc}
\begin{array}{c}
\text { Notation } \\
\text { hconv }
\end{array} & \begin{array}{c}
\text { Meaning } \\
\text { Heat transfer coefficient between skin and environment due } \\
\text { to convection. }
\end{array} \\
\text { To } & \text { Atmospheric temperature. } \\
\sigma & \text { Stefan Boltzmann constant. } \\
\varepsilon & \text { Emissivity of the skin surface } \\
\text { L } & \text { Latent heat of evaporation. } \\
\text { E } & \text { Evaporative heat loss between skin surface and environment. }
\end{array}
$$

The nonlinear radiation term in the boundary condition of eqn. (6) is treated by using iterative procedure as follow $[7,19]$.

$$
\begin{aligned}
& -\left.k \frac{\partial T}{\partial \eta}\right|_{\text {at skin surface }}=h_{\text {conv }}\left(T(0, t)-T_{\infty}\right)+\sigma \varepsilon\left(T^{2}(0, \mathrm{t})-\mathrm{T}_{\infty}^{2}\right)\left(\mathrm{T}(0, t)-T_{\infty}\right)+L E \\
& -\left.k \frac{\partial T}{\partial \eta}\right|_{\text {at skin surface }}=h_{c r}\left(T^{n}(0, t)-T_{\infty}\right)+L E
\end{aligned}
$$

where, $\left.\quad \mathrm{h}_{\mathrm{cr}}=\mathrm{h}_{\text {conv }}\left(\mathrm{T}(0, \mathrm{t})-\mathrm{T}_{\infty}\right)+\sigma \varepsilon\left(\mathrm{T}^{\mathrm{n}-1}(0, \mathrm{t})+\mathrm{T}_{\infty}\right) \quad(\{\mathrm{T}(0, \mathrm{t})\} \mathrm{n}-1) 2+\mathrm{T}_{2} \quad \infty\right)$ $h_{\text {cr }}=h_{\text {conv }}+h_{\text {rad, }}$, where, $T^{n}(0, t)$ are the temperature sequences for $\mathrm{n}=1,2,3, \ldots$ and $\mathrm{T}^{0}(0, \mathrm{t})$ represents an initial guess of temperature, $\left.\mathrm{h}_{\mathrm{rad}}=\sigma \varepsilon\left(\mathrm{T}^{\mathrm{n}-1}(0, \mathrm{t})+\mathrm{T}_{\infty}\right)\left(\{\mathrm{T}(0, \mathrm{t})\}^{\mathrm{n}-1}\right)^{2}+\mathrm{T}^{2}{ }_{\infty}\right)$. The iteration is completed under the convergent condition:

$$
\left\|T^{n}(0, t)-T^{n-1}(0, t)\right\| \leq \delta
$$

where, $\delta$ is iteration tolerance.

The transport of heat within tissue occurs along downwards from the skin surface to the body core hence we can assume negligible heat flux along $\mathrm{x}$-direction. So the boundary conditions are assumed to be

$$
\Gamma_{2}:\left.\frac{\partial T}{\partial x}\right|_{x=0}=0
$$

$$
\Gamma_{3}:\left.\frac{\partial T}{\partial x}\right|_{x=W}=0
$$

Where, $\mathrm{W}$ is the total width of the skin taken along $\mathrm{x}$-direction.

Also the human body maintains its core temperature at a uniform temperature at $37^{\circ} \mathrm{C}$. Therefore, one and two dimensional inner boundary condition is generally taken as

$$
\Gamma_{4}: \mathrm{T}_{\mathrm{b}}=37^{\circ} \mathrm{C}
$$

Where, $\mathrm{T}_{\mathrm{b}}$ is the body core temperature.

\section{Assumptions of the Model}

The anatomical structure of human dermal part makes it reasonable to consider $M=\omega_{b} \rho_{b} c_{b}$ is zero in stratum corneum and stratum germinativum. $\mathrm{qm}$ is also zero in stratum corneum, $\mathrm{M}$ and $\mathrm{qm}$ constant in muscle layer of ST. The assumptions of parameters in the layers of dermal part of this one and two dimensional steady state and transient models are applied as follows:

- Linear shape function has been considered for temperature function $\mathrm{T}^{(\mathrm{i})}$ in each layer depending on the thickness of layers.

The linear shape functions are considered to approximate the temperature profiles in the layers of dermal regions. So for a typical triangular element (e) we take [9].

1. In one dimensional discretization

$$
T^{(\mathrm{e})}=C_{1}^{(\mathrm{e})}+C_{2}^{(\mathrm{e})} x
$$

where, $C_{2}^{(\mathrm{e})}$ and $C_{2}^{(\mathrm{e})}$ are coefficients of $\mathrm{T}^{(\mathrm{e})}$ depending upon the nodal values.

2. In two dimensional discretization

$$
T^{(\mathrm{e})}=C_{1}^{(\mathrm{e})}+C_{2}^{(\mathrm{e})} x+C_{3}^{(\mathrm{e})} y
$$

where, $C_{1}^{(\mathrm{e})}, C_{2}^{(\mathrm{e})}$ and $C_{3}^{(\mathrm{e})}$ are coefficients of $\mathrm{T}^{(\mathrm{e})}$ depending upon the nodal values $T_{1}^{(\mathrm{e})}, T_{2}^{(\mathrm{e})}$ and $T_{3}^{(\mathrm{e})}$ of the typical triangular element (e). The orientation of local nodal coordinate is taken as shown in Figure 3.

- Arterial blood temperature $\mathrm{T}_{\mathrm{a}}$ have been considered zero in stratum corneum and stratum germinativum and $\mathrm{T}_{\mathrm{a}}=\mathrm{T}_{\mathrm{b}}$ in papillary region, reticular region and muscle and subcutaneous tissues.

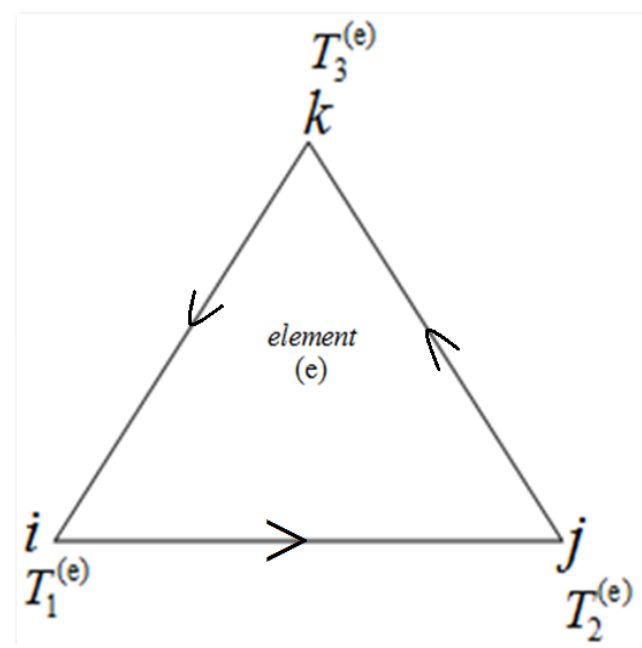

Figure 3: Triangular Element. 
- Blood perfusion has been considered zero in stratum corneum and stratum germinativum. It has been considered as a function of depth in the layers lying between stratum germinativum and subcutaneous tissue.

- Metabolic heat has been taken zero in stratum corneum and it has been considered as a function in depth in the layers lying between stratum corneum and subcutaneous tissue.

- Uniform blood perfusion rate and metabolic heat for males and females have been considered in muscle layer of subcutaneous tissue.

\section{One Dimensional Mathematical Solution of the Model}

The governing eqn. (1) together with one dimensional boundary conditions as in eqn. (2) and (6) is transformed into the vibrational integral form in case of males and females. The element wise vibrational form for male and female are:

$$
\begin{aligned}
I_{\text {male }}^{(\mathrm{e})}=\frac{1}{2} \int_{l e-1}^{l e} & {\left[K\left(\frac{d T^{(\mathrm{e})}}{d x}\right)^{2}+\omega_{b} \rho_{b} c_{b}\left(T_{a}-T^{(\mathrm{e})}\right)^{2}-2_{q m} T^{(\mathrm{e})}-\rho c \frac{\partial T(\mathrm{e})^{2}}{\partial t}\right] d x } \\
+ & \frac{1}{2}\left[h_{c r}\left(T^{(e)}-T_{\infty}\right)^{2}+2 L E_{\text {male }}\right] d \Gamma_{1} \\
I_{\text {female }}^{(\mathrm{e})}=\frac{1}{2} \int_{l e-1}^{l e} & {\left[K\left(\frac{d T^{(\mathrm{e})}}{d x}\right)^{2}+\omega_{b} \rho_{b} c_{b}\left(T_{a}-T^{(\mathrm{e})}\right)^{2}-2_{q m} T^{(\mathrm{e})}-\rho c \frac{\partial T(\mathrm{e})^{2}}{\partial t}\right] d x } \\
& +\frac{1}{2}\left[h_{c r}\left(T^{(e)}-T_{\infty}\right)^{2}+2 L E_{\text {female }}\right] d \Gamma_{1}
\end{aligned}
$$

where $e=1(1) 6$ with $\mathrm{l}_{0}=0$. Next, we differentiate $\mathrm{I}_{\text {male }}$ and $\mathrm{I}_{\text {female }}$ partially with respect to $\mathrm{T}_{\mathrm{i}}$ to minimize $\mathrm{I}_{\text {male }}$ and $\mathrm{I}_{\text {female }}$ and equating to zero. That is

$$
\begin{aligned}
& \frac{\partial\left(I_{\text {male }}\right)}{\partial T_{i}}=\sum_{e=1}^{6} \frac{\partial\left(I_{\text {male }}\right)}{\partial T_{i}}=0 \\
& \frac{\partial\left(I_{\text {female }}\right)}{\partial T_{i}}=\sum_{e=1}^{6} \frac{\partial\left(I_{\text {female }}\right)}{\partial T_{i}}=0
\end{aligned}
$$

where $\mathrm{i}=0(1) 5, I_{\text {female }}=\sum_{e=1}^{6} I_{\text {male }}^{(\mathrm{e})}$ and $I_{\text {female }}=\sum_{e=1}^{6} I_{\text {female }}^{(\mathrm{e})}$

Eqns. (16) and (17) gives the system of linear equations which can be written in matrix form as

$$
[\mathbb{C}]\{\dot{\mathbf{T}}\}+[\mathbb{P}]\{\mathbf{T}\}=\{\mathbb{Q}\}
$$

where $[\mathrm{C}]$ and $[\mathrm{P}]$ are $6 \times 6$ order matrices, $\{\dot{\mathbf{T}}\}$ and $\{\mathbf{T}\}$ are $6 \times 1$ order column matrices. The elements of $[\mathrm{C}]$ and $[\mathrm{P}]$ are related with the physical and physiological parameters.

Using Crank-Nicolson in eqn. (18) [6,16];

$$
\left(\frac{1}{\Delta t} \mathbb{C}+\frac{1}{2} \mathbb{P}\right)\{\mathrm{T}\}^{(\mathrm{i}+1)}=\left(\frac{1}{\Delta t} \mathbb{C}-\frac{1}{2} \mathbb{C}\right)\{\mathrm{T}\}^{(\mathrm{i})}+\{\mathbb{Q}\}
$$

Where, $\Delta \mathrm{t}$ is time interval and $\left\{\mathrm{T}^{(0)}\right\}$ is the $6 \times 1$ order column vector for the initial nodal temperature. The eqn. (19) is repeatedly solved to get the nodal temperature in case of transient problem. But the solution of steady state case is obtained by solving the system of 6-linear algebraic equations represented in matrix form as given by eqn. (20).

$$
[\mathbb{P}]\{\mathrm{T}\}=\{\mathbb{Q}\}
$$

\section{Two Dimensional Mathematical Solution of the Model}

The governing eqn. (1) together with two dimensional boundary conditions is transformed into the variational form for males and females skin layers are given in eqns. (21) and (22):

$$
\begin{aligned}
\mathrm{I}_{\text {male }}= & \frac{1}{2} \iint_{\Omega}\left[k\left(\left(\frac{\partial T}{\partial x}\right)^{2}+\frac{\partial T}{\partial y}\right)^{2}+w \rho_{b} c_{b}\left(T_{a}-T\right)^{2}-2 q m T+\rho c \frac{\partial T^{2}}{\partial t}\right] d \Omega+ \\
& \frac{1}{2} \int\left[h_{\Gamma_{1}}\left(T-T_{\infty}\right)^{2}+2 L E_{\text {male }}\right] d \Gamma_{1} \\
\mathrm{I}_{\text {female }} & =\frac{1}{2} \iint_{\Omega}\left[k\left(\left(\frac{\partial T}{\partial x}\right)^{2}+\frac{\partial T}{\partial y}\right)^{2}+w \rho_{b} c_{b}\left(T_{a}-T\right)^{2}-2 q m T+\rho c \frac{\partial T^{2}}{\partial t}\right] d \Omega+ \\
& \frac{1}{2} \int\left[h_{\Gamma_{1}}\left(T-T_{\infty}\right)^{2}+2 L E_{\text {female }}\right] d \Gamma_{1}
\end{aligned}
$$

Where, $\Omega$ is the domain of the region of dermal part considered and $\Gamma 1$ is the outer skin boundary.

Now express the eqns. (21) and (22) as a sum of E elemental quantities I(e) as:

$$
I_{\text {male }}=\sum_{e=1}^{\mathbb{E}} I_{\text {male }}^{(\mathrm{e})}
$$

where,

$$
\begin{aligned}
& \mathrm{I}_{m a l e}^{(e)}=\frac{1}{2} \iint_{\Omega(e)}\left[k^{(e)}\left(\left(\frac{\partial T^{(e)}}{\partial x}\right)^{2}+\frac{\partial T^{(e)}}{\partial y}\right)^{2}+w_{b}^{(e)} \rho_{b} c_{b}\left(T_{a}-T^{(e)}\right)^{2}-2 q_{m}^{(e)} T^{(e)}+\rho c \frac{\left.\partial T^{(e)}\right)^{2}}{\partial t}\right] d \Omega^{(e)}+ \\
& \frac{1}{2} \int_{\Gamma^{(0)}}\left[h_{c r}\left(T^{(e)}-T_{\infty}\right)^{2}+2 L E_{\text {male }} T^{(0)}\right] d \Gamma_{1}^{(e)}
\end{aligned}
$$

And

$$
I_{\text {female }}=\sum_{e=1}^{\mathbb{E}} I_{\text {female }}^{(\mathrm{e})}
$$

where,

$$
\begin{aligned}
& \mathrm{I}_{\text {fermele }}^{(e)}=\frac{1}{2} \iint_{\Omega(e)}\left[k^{(e)}\left(\left(\frac{\partial T^{(e)}}{\partial x}\right)^{2}+\frac{\partial T^{(e)}}{\partial y}\right)^{2}+w_{b}^{(e)} \rho_{b} c_{b}\left(T_{a}-T^{(e)}\right)^{2}-2 q_{m}^{(e)} T^{(e)}+\rho c \frac{\partial T^{(e)^{2}}}{\partial t}\right] d \Omega^{(e)}+ \\
& \frac{1}{2} \int\left[h_{c r}\left(T^{(e)}-T_{\infty}\right)^{2}+2 L E_{\text {female }} T^{(e)}\right] d \Gamma_{1}^{(e)}
\end{aligned}
$$

Here, $\Omega^{(\mathrm{e})}$ is the domain of the nodal element (e) and $T_{1}^{(\mathrm{e})}$ is the boundary of outer skin elements. For the minimization of the functional $\mathrm{I}_{\text {male }}$, and $\mathrm{I}_{\text {female }}$ we have

$$
\begin{aligned}
& \frac{\partial\left(I_{\text {male }}\right)}{\partial T_{i}}=\sum_{e=1}^{\mathbb{E}} \frac{\partial\left(I_{\text {male }}^{(\mathrm{e})}\right)}{\partial T_{i}}=0, i=1,2, \ldots, N \\
& \frac{\partial\left(I_{\text {female }}\right)}{\partial T_{i}}=\sum_{e=1}^{\mathbb{E}} \frac{\partial\left(I_{\text {female }}^{(\mathrm{e})}\right)}{\partial T_{i}}=0, i=1,2, \ldots, N
\end{aligned}
$$

where, $\mathrm{N}$ is the total number of nodes considered.

Differentiate eqns. (27) and (28) with respect to each nodal temperature, except as the core boundary and set the derivatives equal to zero. The eqn. (27) and (28) leads to a linear system of differential equations. Then the system in matrix form can be expressed as:

$$
\left[\mathbb{C}^{*}\right]\{\dot{\mathbf{T}}\}+\left[\mathbb{P}^{*}\right]\{\mathbf{T}\}=\left\{\mathbb{Q}^{*}\right\}
$$

where, $\left[\mathbb{C}^{*}\right],\left[\mathbb{P}^{*}\right]$ are $\mathrm{N} \times \mathrm{N}$ order matrices and $\{\mathbf{T}\},\{\dot{\mathbf{T}}\}$ with $\dot{\mathbf{T}}=\frac{\partial T}{\partial t}$ are $\mathrm{N} \times 1$ order column matrices. The elements of $\left[\mathbb{C}^{*}\right]$ and $\left[\mathbb{P}^{*}\right]$ are related with the physical and physiological parameters. Now CrankNicolson method is applied to solve the system of eqn. (29) with respect to time. From Crank-Nicolson method, eqn. (29) is written as eqn. (30).

$$
\left(\frac{1}{\Delta t} \mathbb{C}^{*}+\frac{1}{2} \mathbb{P}^{*}\right)\{\mathrm{T}\}^{(\mathrm{i}+1)}=\left(\frac{1}{\Delta t} \mathbb{C}^{*}+\frac{1}{2} P\right)\{\mathrm{T}\}^{(\mathrm{i})}+\left\{\mathbb{Q}^{*}\right\}
$$


where, $\Delta \mathrm{t}$ is time interval and $\{\mathrm{T}\}^{(\mathrm{i})}$ is the nodal temperatures. The eqn. (30) repeatedly solve to get the nodal temperature in case of two dimensional transient problem. But the solution of steady case is obtained by solving the system of eqn. (31).

$$
\left[\mathbb{P}^{*}\right]\{\mathrm{T}\}=\left\{\mathbb{Q}^{*}\right\}
$$

\section{The Parameter Values Used in the Model for Sweating Effect Analysis}

The parameter values of Table 1 have been used for the numerical simulation on one and two dimensional steady state and transient solutions. The skin is structured in mainly three layers: the epidermis, the dermis and the subcutaneous tissue. The superficial epidermis is approximately (75-150) $\mu \mathrm{m}$ in thickness. The second layer is the dermis which is approximately $1-4 \mathrm{~mm}$. The third layer is subcutaneous tissue (ST) which is composed of loose fatty connective tissue. The thickness of subcutaneous tissue is approximately $(0.4-3) \mathrm{cm}$. The thickness of subcutaneous tissue varies considerably over the surface of the body [13]. The thickness of subcutaneous part varies with age, sex, race, endocrine, and nutritional status of the individual. The thicknesses of dermal layers considered in this model are presented in the Table 2. The sweating rate for males and females is calculated using eqns. (4) and (5).

\section{One Dimensional Numerical Results and Discussion}

\section{Steady state results}

The results of the analysis for the steady state case of males and females are presented through the graphs in the Figures $4-6$ by solving the system of eqn. (20).

Figure 4 represents the tissue temperature differences of males and females at $\mathrm{T}_{\infty}=35^{\circ} \mathrm{C}$. Males tissue temperatures $\mathrm{T}_{0}, \mathrm{~T}_{1}, \mathrm{~T}_{2}, \mathrm{~T}_{3}, \mathrm{~T}_{4}$ and $\mathrm{T}_{5}$ are increased by an average of $0.07^{\circ} \mathrm{C}$ in comparison to females. The results suggest that the skin temperature in males is slightly higher relative to females when atmospheric temperature $T_{\infty}$ falls below the body core. This may be due to less sweating effect in heat loss in males/ females body because atmospheric temperature is below than body temperature.

Accordingly, Figure 5 describes the tissue temperature difference of males and females at $\mathrm{T}_{\infty}=45^{\circ} \mathrm{C}$. Males nodal temperatures $\mathrm{T}_{0}, \mathrm{~T}_{1}, \mathrm{~T}_{2}$, $\mathrm{T}_{3}, \mathrm{~T}_{4}$ and $\mathrm{T}_{5}$ are decreased by around $0.05^{\circ} \mathrm{C}$ in comparison to females.

\begin{tabular}{|c|c|c|}
\hline Parameters & Value & Unit \\
\hline $\mathrm{K}^{(1)}$ & $0: 20934$ & $\mathrm{~W} / \mathrm{m}^{\circ} \mathrm{C}$ \\
\hline $\mathrm{K}^{(2)}$ & $0: 20934$ & $\mathrm{~W} / \mathrm{m}^{\circ} \mathrm{C}$ \\
\hline $\mathrm{K}^{(3)}$ & $0: 31401$ & $\mathrm{~W} / \mathrm{m}^{\circ} \mathrm{C}$ \\
\hline $\mathrm{K}^{(4)}$ & $0: 31401$ & $\mathrm{~W} / \mathrm{m}^{\circ} \mathrm{C}$ \\
\hline $\mathrm{K}^{(5)}$ & $0: 41868$ & $\mathrm{~W} / \mathrm{m}^{\circ} \mathrm{C}$ \\
\hline $\mathrm{L}$ & $2: 4 \times 10^{6}$ & $\mathrm{~J}=\mathrm{kg}$ \\
\hline $\mathrm{h}$ & $6: 2802$ & $\mathrm{~W} / \mathrm{m}^{2} \times^{\circ} \mathrm{C}$ \\
\hline$\rho$ & 1050 & $\mathrm{Kg} / \mathrm{m}^{3}$ \\
\hline $\mathrm{C}$ & $3475: 044$ & $\mathrm{~J} / \mathrm{kg}^{\circ} \mathrm{C}$ \\
\hline $\mathrm{M}$ & $1255: 67$ & $\mathrm{~W} / \mathrm{kg}^{\circ} \mathrm{C}$ \\
\hline $\mathrm{S}$ & 744 & $\mathrm{~W} / \mathrm{m}^{3}$ \\
\hline
\end{tabular}

Table 1: The thermal properties of human skin layers $[2,5,11]$.

\begin{tabular}{|c|c|c|c|c|c|c|}
\hline Thicknesses & $\mathrm{I}_{1}$ & $\mathrm{I}_{2}$ & $\mathrm{I}_{3}$ & $\mathrm{I}_{4}$ & $\mathrm{I}_{5}$ & $\mathrm{I}_{6}$ \\
\hline For males & $0: 0005$ & $0: 001$ & $0: 002$ & $0: 0035$ & $0: 0055$ & $0: 0090$ \\
\hline For Females & $0: 0005$ & $0: 001$ & $0: 002$ & $0: 0035$ & $0: 0060$ & $0: 01$ \\
\hline
\end{tabular}

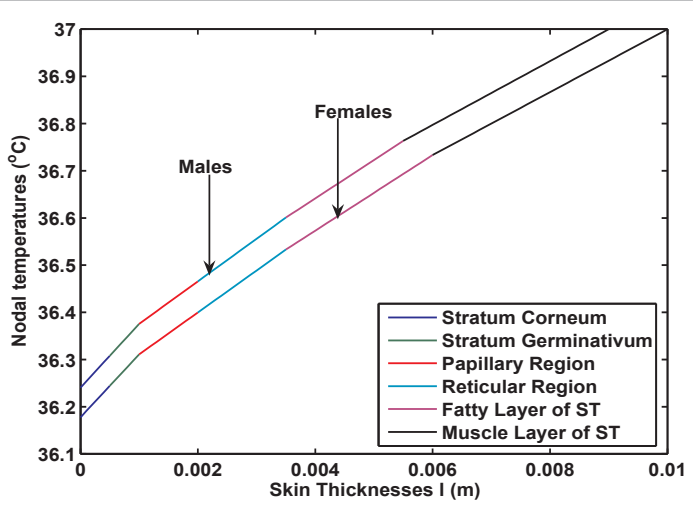

Figure 4: One dimensional steady state tissue temperature of females and males at $\mathrm{T} \infty=35^{\circ} \mathrm{C}$ for sweating effect analysis.

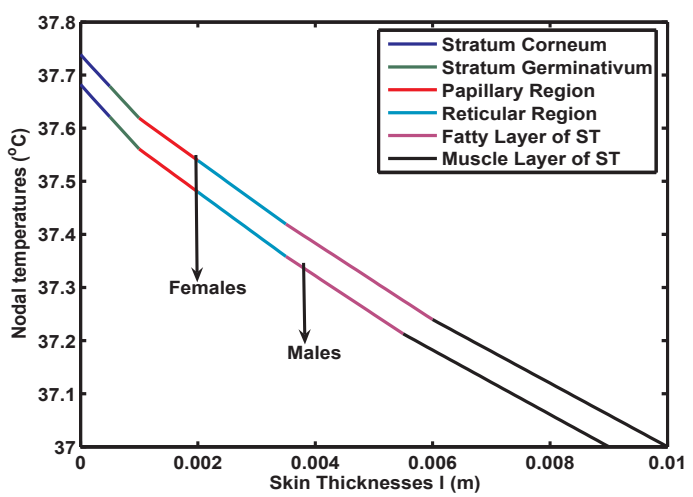

Figure 5: One dimensional steady state tissue temperature of females and males at $\mathrm{T} \infty=45^{\circ} \mathrm{C}$ for sweating effect analysis.

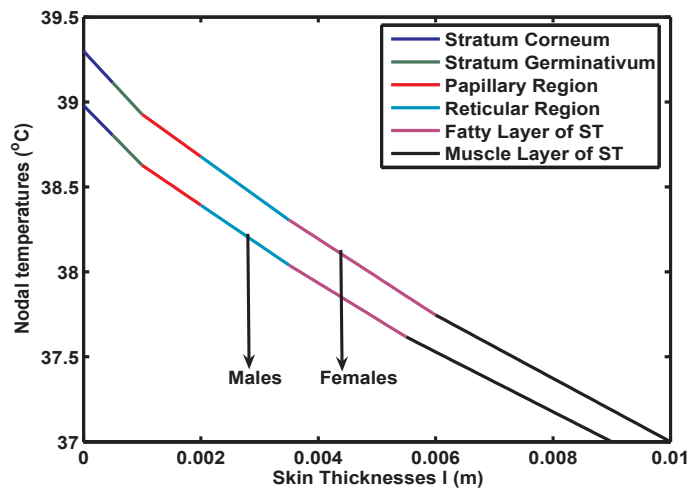

Figure 6: One dimensional steady state tissue temperature of females and males at $\mathrm{T}=55^{\circ} \mathrm{C}$ for sweating effect analysis.

Likewise, Figure 6 analyses that males nodal temperatures $T_{0}$, $\mathrm{T}_{1}, \mathrm{~T}_{2}, \mathrm{~T}_{3}, \mathrm{~T}_{4}$ are decreased by around $0.30^{\circ} \mathrm{C}$ and $\mathrm{T} 5$ is decreased by around $0.10^{\circ} \mathrm{C}$ as compared to females. Here, we conclude that males tissue temperature is slightly lower as compared to females when To exceeds above $37^{\circ} \mathrm{C}$. This is because sweating effect is high during heat loss by our body when atmospheric temperature is above body core temperature.

\section{Unsteady state results}

The system of eqn. (19) is used for the solution of transient result. The males and females each steady state tissue nodal temperature are 
Citation: Gurung DB, Acharya S (2018) Sweating Effect on Males and Females Body Temperature Variation. J Appl Computat Math 7: 401. doi: 10.4172/2168-9679.1000401

Page 6 of 11

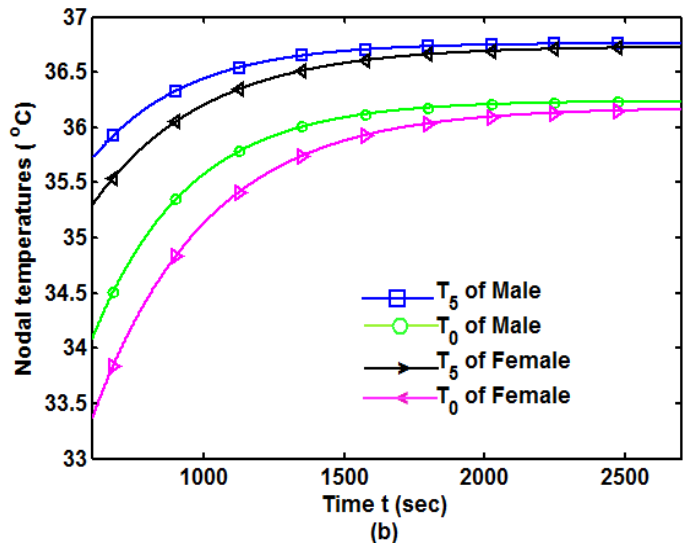

Figure 7: One dimensional transient nodal temperature of females and males at $\mathrm{T}=35^{\circ} \mathrm{C}$ for sweating effect analysis.

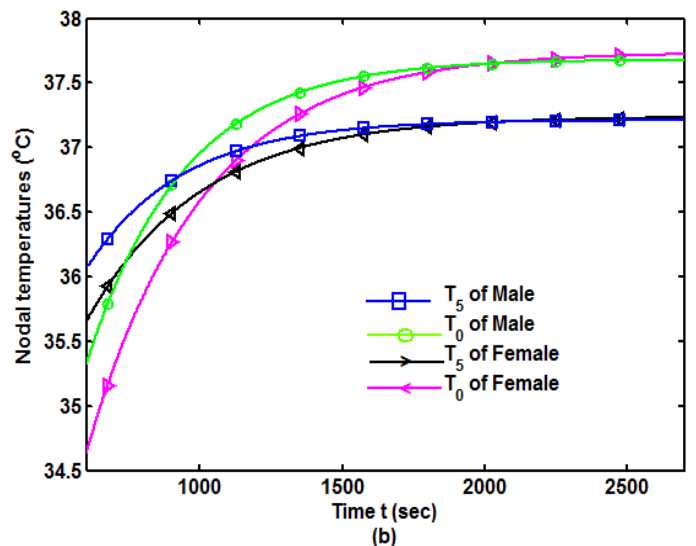

Figure 8: One dimensional transient nodal temperature of females and males at $T_{\infty}=45^{\circ} \mathrm{C}$ for sweating effect analysis

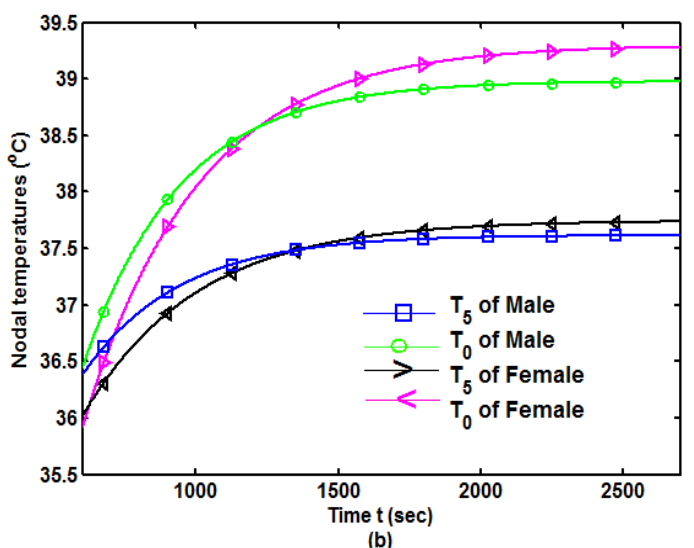

Figure 9: One dimensional transient nodal temperature of females and males at $T \infty=55^{\circ} \mathrm{C}$ for sweating effect analysis. presented through the graphs in the Figures 7-9 for time up to 2700 seconds (45 minutes).

The nodal temperatures and time required to reach the steady temperature at each node for $\mathrm{T}_{\infty}=35^{\circ} \mathrm{C}, 45^{\circ} \mathrm{C}, 55^{\circ} \mathrm{C}$ for males and females body due to sweating effect are presented in Tables 3-6.

The unsteady state results demonstrate that steady state temperature of each node is achieved earlier in males as compare to females.

\section{Two Dimensional Numerical Results and Discussion}

\section{Steady state results}

The notations which are used in two dimensional figures and tables are represented interfaces steady nodal temperatures in simulation. The details are as follows:

$$
\begin{aligned}
& \text { Notation Meaning } \\
& \mathrm{T}_{\mathrm{SC}} \quad \text { Outer skin steady nodal temperature of stratum corneum, } \\
& \mathrm{T}_{\mathrm{SG}} \quad \text { Interface steady nodal temperature between stratum corneum and }
\end{aligned}
$$

The results of the analysis for temperature distribution at the interfaces of the dermal sub regions are presented through the graphs Figures 10-15 for males and females dermal layers in case of steady state.

The observed tissue nodal temperatures of males and females are presented at Tables 7 and 8 , respectively.

\section{Unsteady state results}

The results of the analysis for nodal temperature distribution at the interfaces of the dermal sub regions are presented through the graphs in Figures 16-21 for males and females dermal layers in transient case. Figures 16-21 represent the tissue nodal temperatures of females and males in two dimensional unsteady state cases. Figures 16 and 17 reveal that tissues temperatures of males are increased by around $0.05^{\circ} \mathrm{C}$ for

\begin{tabular}{|c|c|c|c|c|c|c|}
\hline Ambient temperature & & & state nc & es of $\mathrm{m}$ & & \\
\hline $\mathrm{T}_{\infty}\left({ }^{\circ} \mathrm{C}\right)$ & $T_{0}$ & $T_{1}$ & $T_{2}$ & $\mathbf{T}_{3}$ & $T_{4}$ & $T_{5}$ \\
\hline 35 & $36: 24$ & $36: 30$ & $36: 37$ & $36: 46$ & $36: 60$ & $36: 76$ \\
\hline 45 & $37: 68$ & $37: 62$ & $37: 56$ & $37: 47$ & $37: 35$ & $37: 21$ \\
\hline 55 & $38: 97$ & $38: 79$ & $38: 62$ & $38: 37$ & $38: 04$ & $37: 60$ \\
\hline
\end{tabular}
$\mathrm{T}_{\mathrm{SC}}, \mathrm{T}_{\mathrm{SG}}, \mathrm{T}_{\mathrm{PR}}, \mathrm{T}_{\mathrm{RL}}, \mathrm{T}_{\mathrm{FS}}$ and $0.08^{\circ} \mathrm{C}$ for $\mathrm{T}_{\mathrm{MS}}$ in comparison to females at $\mathrm{T}_{\infty}=35^{\circ} \mathrm{C}$. Likewise Figures 18 and 19 observe that tissues temperatures of males are decreased by around $0.20^{\circ} \mathrm{C}$ for $\mathrm{T}_{\mathrm{SC}}, \mathrm{T}_{\mathrm{SG}}, \mathrm{T}_{\mathrm{PR}}, \mathrm{T}_{\mathrm{RL}}, \mathrm{T}_{\mathrm{FS}}$ and $0.08^{\circ} \mathrm{C}$ for $\mathrm{T}_{\mathrm{MS}}$ in comparison to females at $\mathrm{T} \infty=45^{\circ} \mathrm{C}$. Moreover, figures 20 and 21 present that tissues temperatures of males are decreased by around $0.18^{\circ} \mathrm{C}$ for nodes of $\mathrm{T}_{\mathrm{SC}}, \mathrm{T}_{\mathrm{SG}}, \mathrm{T}_{\mathrm{PR}}, \mathrm{T}_{\mathrm{RL}}, \mathrm{T}_{\mathrm{FS}}$ and $0.09^{\circ} \mathrm{C}$ for $\mathrm{TMS}$ in comparison to females at $\mathrm{T}_{\infty}=55^{\circ} \mathrm{C}$. Same conclusion are exhibited in two dimensional results as in one dimension. But two dimensional tissue temperature is higher as compared to one dimensional results. In two dimensional study the effect of parameters are higher due to the case of two dimensional discretization of skin layers.

Table 3: One dimensional steady state nodal temperature of males for sweating effect analysis. 
Citation: Gurung DB, Acharya S (2018) Sweating Effect on Males and Females Body Temperature Variation. J Appl Computat Math 7: 401. doi: 10.4172/2168-9679.1000401

Page 7 of 11

\begin{tabular}{|c|c|c|c|c|c|c|}
\hline \multirow{2}{*}{\begin{tabular}{|c|} 
Ambient temperature \\
$\mathrm{T}_{\infty}\left({ }^{\circ} \mathrm{C}\right)$ \\
\end{tabular}} & \multicolumn{6}{|c|}{ Steady state nodal temperatures of males $\left({ }^{\circ} \mathrm{C}\right)$} \\
\hline & $T_{0}$ & $T_{1}$ & $T_{2}$ & $\mathbf{T}_{3}$ & $T_{4}$ & $T_{5}$ \\
\hline 35 & 2636 & 2480 & 2389 & 2360 & 2162 & 2100 \\
\hline 45 & 2452 & 2380 & 2291 & 2250 & 2183 & 2120 \\
\hline 50 & 2309 & 2341 & 2299 & 2255 & 2262 & 2168 \\
\hline
\end{tabular}

Table 4: One dimensional males' steady state time for sweating effect analysis for each node.

\begin{tabular}{|c|c|c|c|c|c|c|}
\hline \multirow{2}{*}{$\begin{array}{c}\text { Ambient temperature } \\
\qquad \mathrm{T}_{\infty}\left({ }^{\circ} \mathrm{C}\right)\end{array}$} & \multicolumn{6}{|c|}{ Steady state nodal temperatures of males $\left({ }^{\circ} \mathrm{C}\right)$} \\
\hline & $T_{0}$ & $\mathrm{~T}_{1}$ & $T_{2}$ & $\mathbf{T}_{3}$ & $\mathrm{~T}_{4}$ & $T_{5}$ \\
\hline 35 & $36: 17$ & $36: 24$ & $36: 31$ & $36: 39$ & $36: 53$ & $36: 70$ \\
\hline 45 & $37: 73$ & $37: 67$ & $37: 61$ & $37: 53$ & $37: 41$ & $37: 25$ \\
\hline 55 & $39: 30$ & $39: 11$ & $38: 92$ & $38: 67$ & $38: 30$ & $37: 70$ \\
\hline
\end{tabular}

Table 5: One dimensional steady state nodal temperatures of females for sweating effect analysis.

\begin{tabular}{|c|c|c|c|c|c|c|}
\hline Ambient temperature & \multicolumn{5}{|c|}{ Steady state nodal temperatures of males ( $\left.{ }^{\circ} \mathrm{C}\right)$} \\
\hline $\mathbf{T}_{\infty}\left({ }^{\circ} \mathbf{C}\right)$ & $\mathbf{T}_{\mathbf{0}}$ & $\mathbf{T}_{\mathbf{1}}$ & $\mathbf{T}_{\mathbf{2}}$ & $\mathbf{T}_{\mathbf{3}}$ & 2430 \\
\hline 35 & 2700 & 2680 & 2473 & 239 & 239 \\
\hline 45 & 2554 & 2500 & 2442 & 2351 & 2375 \\
\hline 55 & 2510 & 2420 & 2351 & 2315 & $\mathbf{T}_{\mathbf{4}}$ \\
\hline
\end{tabular}

Table 6: One dimensional females' steady state time for sweating effect analysis for each node.

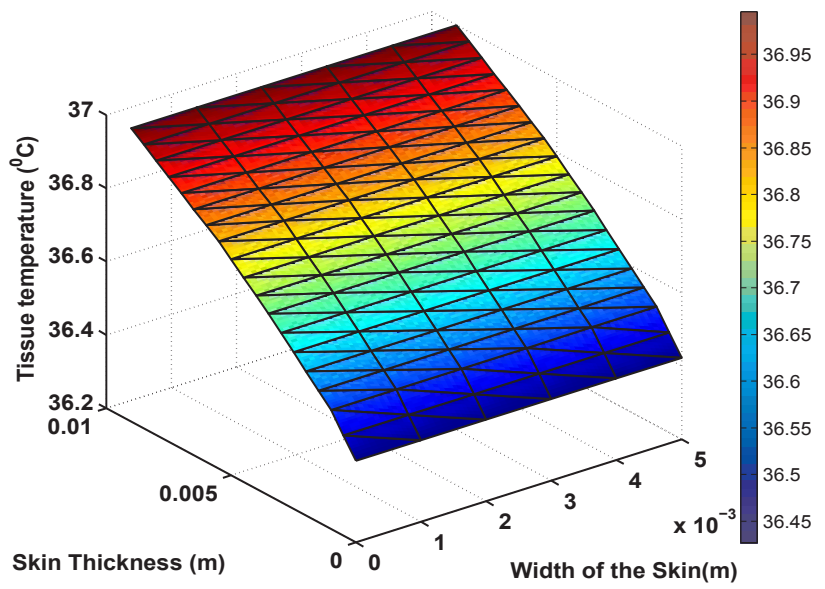

Figure 10: Two dimensional tissue temperature of males at $T \infty=35^{\circ} \mathrm{C}$ for sweating effect analysis.

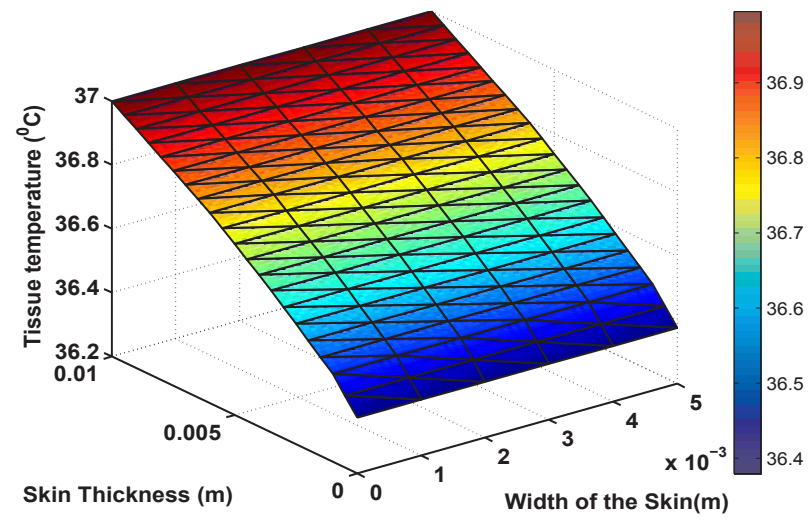

Figure 11: Two dimensional tissue temperature of females at $\mathrm{T}^{\infty}=35^{\circ} \mathrm{C}$ for sweating effect analysis.

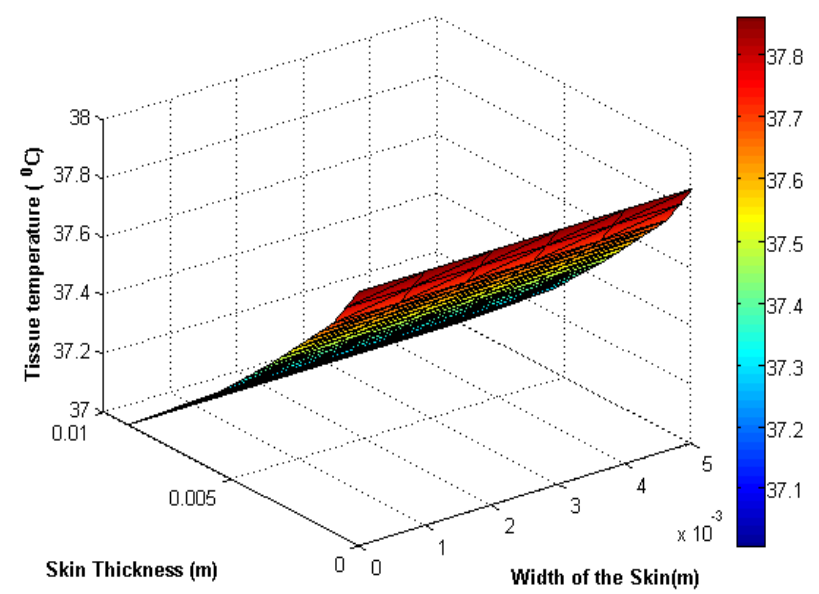

Figure 12: Two dimensional tissue temperature of males at $\mathrm{T}^{\infty}=45^{\circ} \mathrm{C}$ for sweating effect analysis.

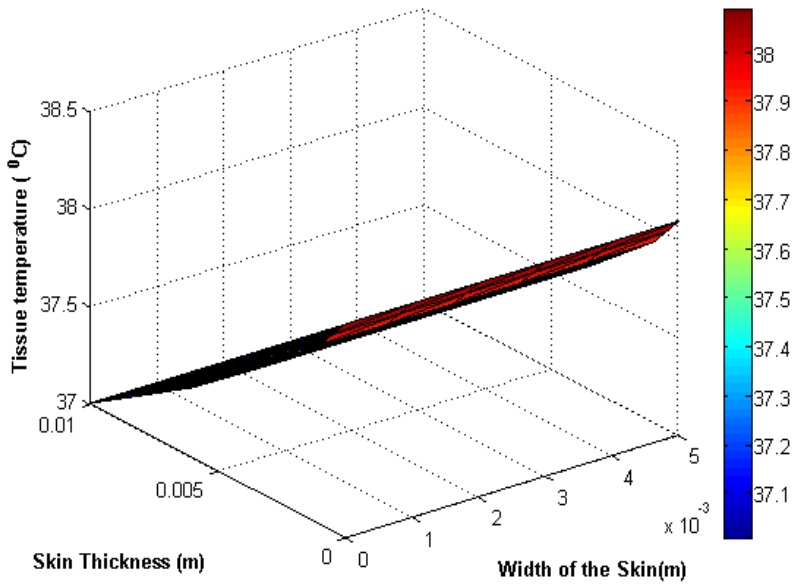

Figure 13: Two dimensional tissue temperature of females at $T^{\infty}=45^{\circ} \mathrm{C}$ for sweating effect analysis. 


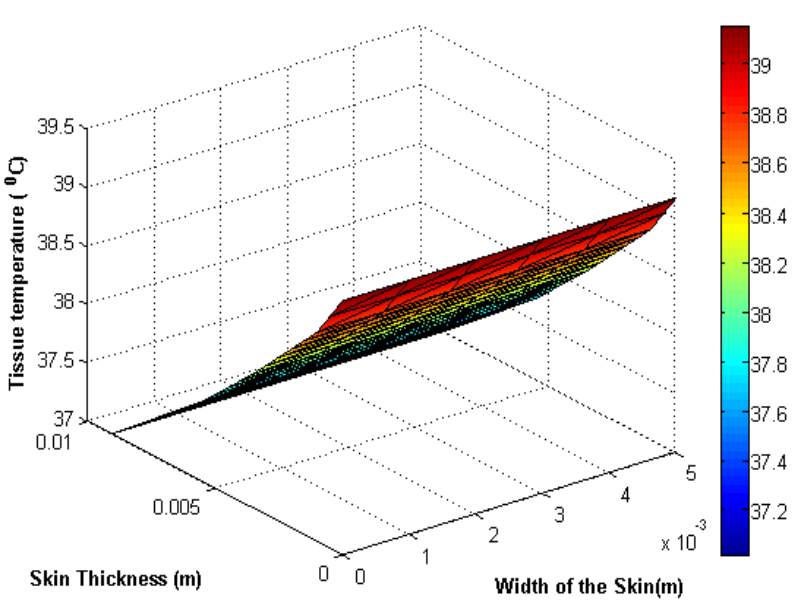

Figure 14: Two dimensional tissue temperature of males at $\mathrm{T}_{\infty}=55^{\circ} \mathrm{C}$ for sweating effect analysis.

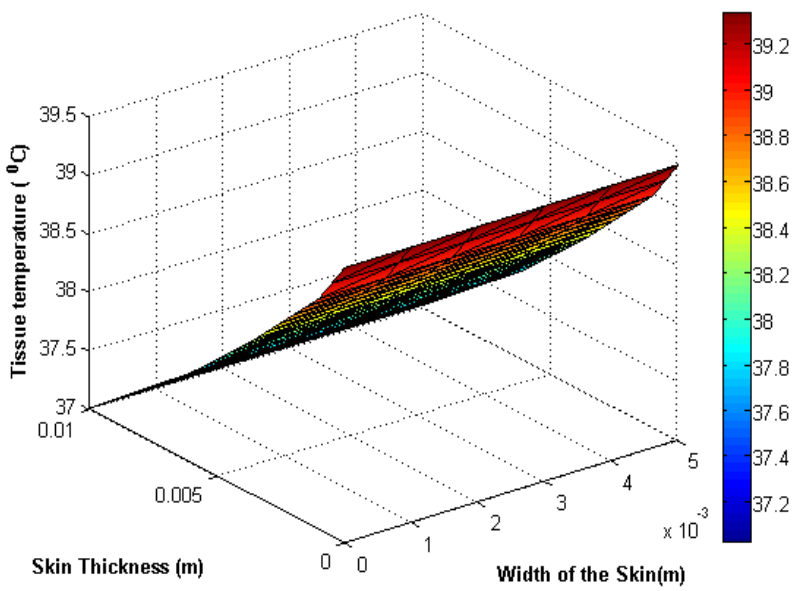

Figure 15: Two dimensional tissue temperature of females at $\mathrm{T}_{\infty}=55^{\circ} \mathrm{C}$ for sweating effect analysis.

\begin{tabular}{|c|c|c|c|c|c|c|}
\hline Ambient temperature & \multicolumn{5}{|c|}{ Steady state nodal temperatures of males ( $\left.{ }^{\circ} \mathrm{C}\right)$} \\
\hline $\left.\mathbf{T}_{\mathbf{\infty}}{ }^{\circ} \mathbf{C}\right)$ & $\mathbf{T}_{\mathbf{S C}}$ & $\mathbf{T}_{\mathbf{S G}}$ & $\mathbf{T}_{\mathbf{P R}}$ & $\mathbf{T}_{\mathbf{R L}}$ & $36: 58$ & $36: 68$ \\
\hline 35 & $36: 42$ & $36: 47$ & $36: 51$ & $37: 60$ & $37: 45$ \\
\hline 45 & $37: 86$ & $37: 78$ & $37: 71$ & $38: 52$ & $37: 81$ \\
\hline 55 & $39: 16$ & $38: 97$ & $38: 77$ & $38: 14$ \\
\hline
\end{tabular}

Table 7: Two dimensional steady state nodal temperatures of males for sweating effect analysis.

\begin{tabular}{|c|c|c|c|c|c|c|}
\hline Ambient temperature & \multicolumn{5}{|c|}{ Steady state nodal temperatures of males $\left({ }^{\circ} \mathrm{C}\right)$} \\
\hline $\left.\mathbf{T}_{\mathbf{\infty}}{ }^{\circ} \mathbf{C}\right)$ & $\mathbf{T}_{\mathbf{S C}}$ & $\mathbf{T}_{\mathbf{S G}}$ & $\mathbf{T}_{\mathbf{P R}}$ & $\mathbf{T}_{\mathbf{R L}}$ & $36: 54$ & $36: 64$ \\
\hline 35 & $36: 37$ & $36: 42$ & $36: 47$ & $37: 79$ & $37: 62$ \\
\hline 45 & $38: 09$ & $38: 00$ & $37: 91$ & $38: 71$ & $37: 73$ \\
\hline 55 & $39: 34$ & $39: 15$ & $38: 96$ & $38: 33$ \\
\hline
\end{tabular}

Table 8: Two dimensional steady state nodal temperatures of females for sweating effect analysis.

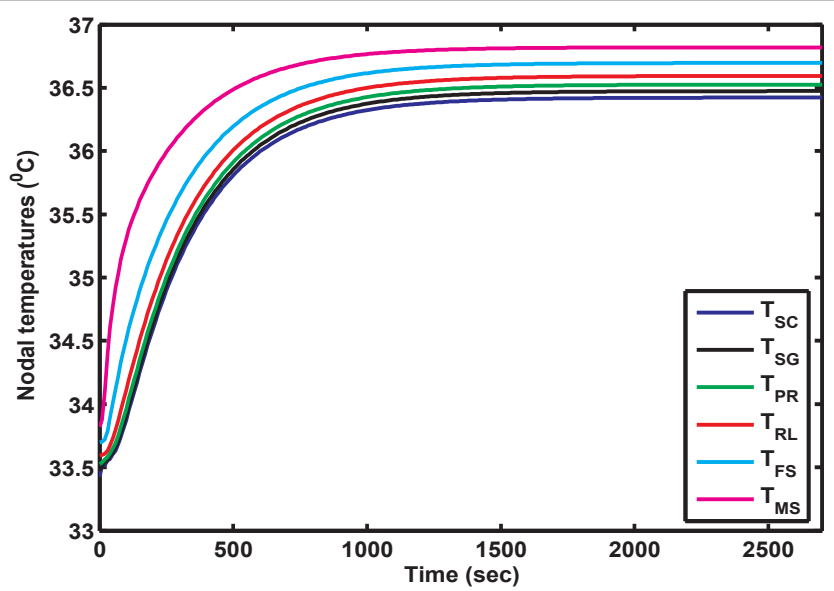

Figure 16: Two dimensional tissue nodal temperature of males at $\mathrm{T}_{\infty}=35^{\circ} \mathrm{C}$ for sweating effect analysis.

\section{Convergence of Solution}

Initially, the mesh of size 180 triangular elements for males and 200 triangular elements for females are constructed for two dimensional convergence study of tissue temperature in case of males and females. We then discretized each triangle into four sub-triangles by joining the midpoint of each side of the triangles. We repeat this mesh construction process up to three times. The temperatures distribution is then shown

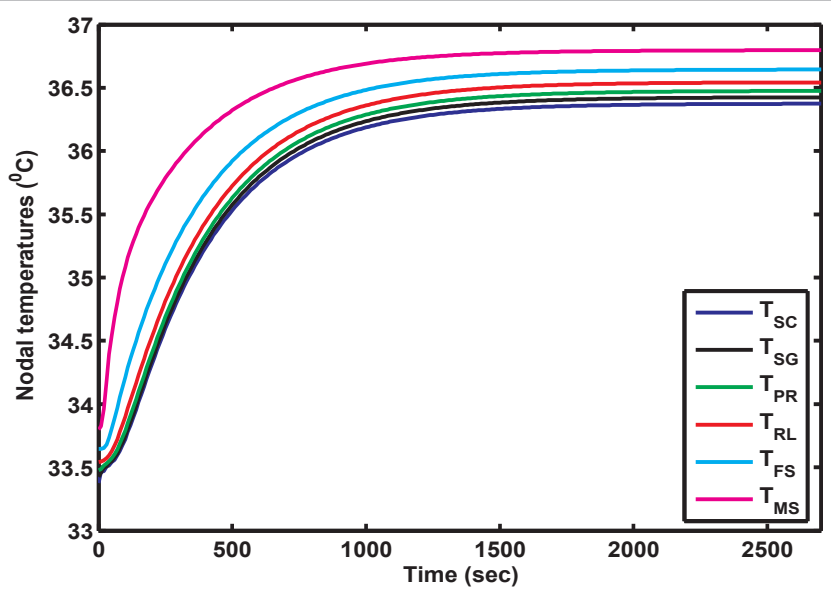

Figure 17: Two dimensional tissue nodal temperature of females at $\mathrm{T}^{\infty}=35^{\circ} \mathrm{C}$ for sweating effect analysis.

in Figures 22-27 at different mesh sizes for sweating effect analysis.

The $\mathrm{T}_{\mathrm{SC}}$ of males and females are tabulated in Tables 9 and 10 , respectively. We conclude from Tables 9 and 10, the $\mathrm{T}_{\mathrm{SC}}$ of males and females are $37.83^{\circ} \mathrm{C}$ and $38.09^{\circ} \mathrm{C}$, respectively for different mesh sizes at atmospheric temperature $\mathrm{T}_{\infty}=45^{\circ} \mathrm{C}$. The convergence value of $\mathrm{T}_{\mathrm{SC}}$ differ between males and females due to the cause of sweating and subcutaneous fat variation between males and females. 
Citation: Gurung DB, Acharya S (2018) Sweating Effect on Males and Females Body Temperature Variation. J Appl Computat Math 7: 401. doi: 10.4172/2168-9679.1000401

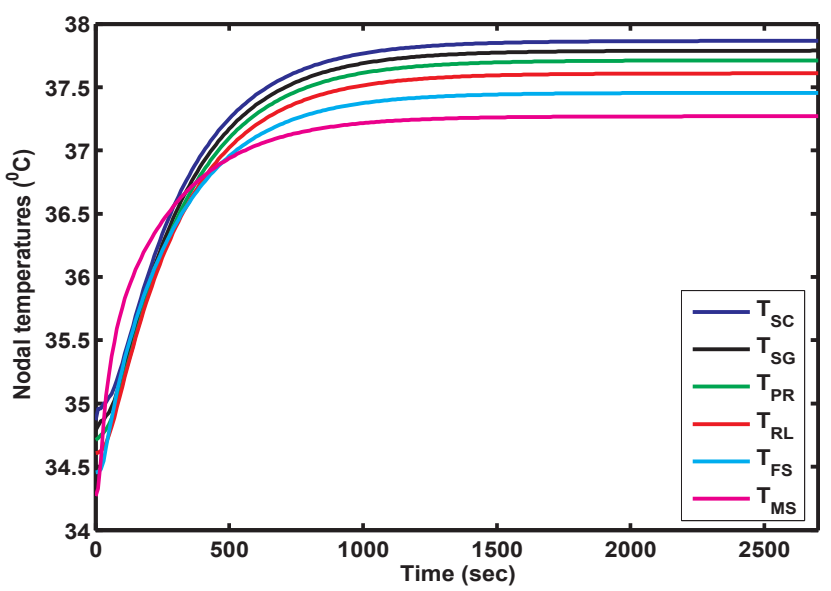

Figure 18: Two dimensional tissue nodal temperature of males at $T \infty=45^{\circ} \mathrm{C}$ for sweating effect analysis.

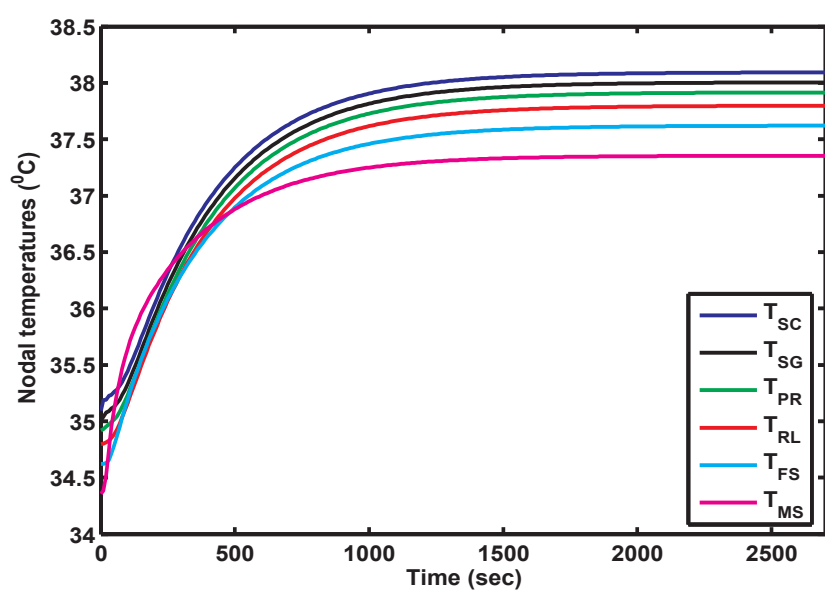

Figure 19: Two dimensional tissue nodal temperature of females at $\mathrm{T}^{\infty}=45^{\circ} \mathrm{C}$ for sweating effect analysis.

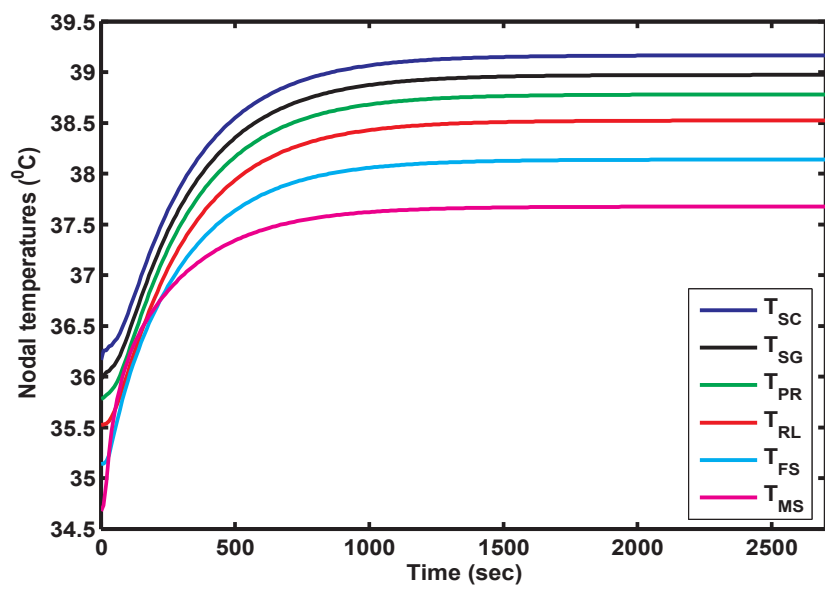

Figure 20: Two dimensional tissue nodal temperature of males at $\mathrm{T} \infty=55^{\circ} \mathrm{C}$ for sweating effect analysis.

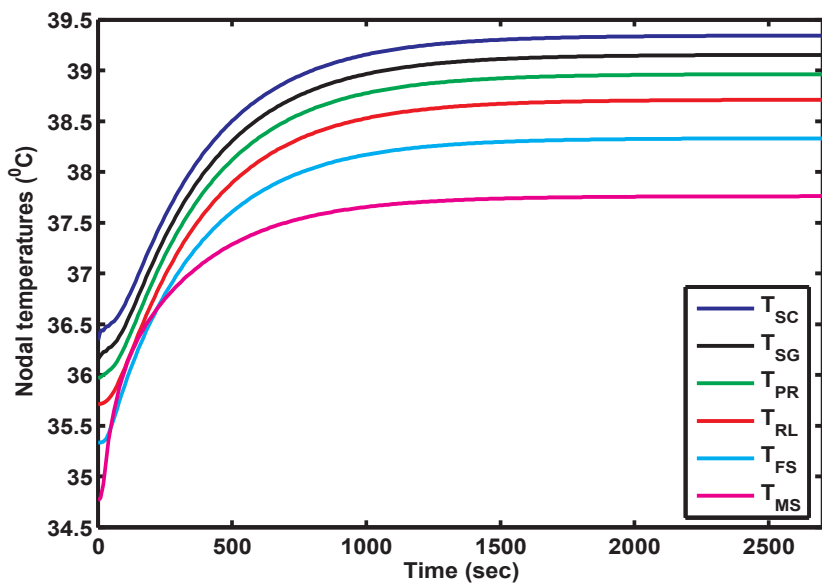

Figure 21: Two dimensional tissue nodal temperature of females at $T_{\infty}=55^{\circ} \mathrm{C}$ for sweating effect analysis.

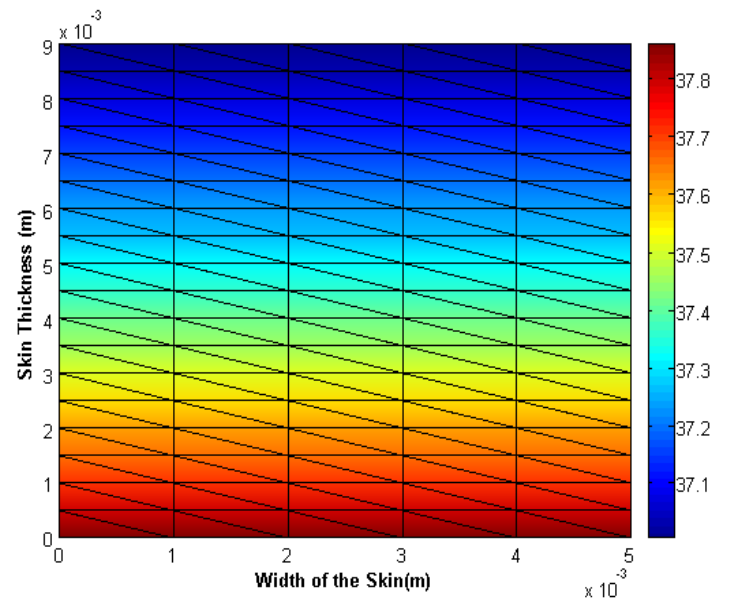

Figure 22: Temperature distribution of males skin layers at mesh of size 180 elements for sweating effect analysis.

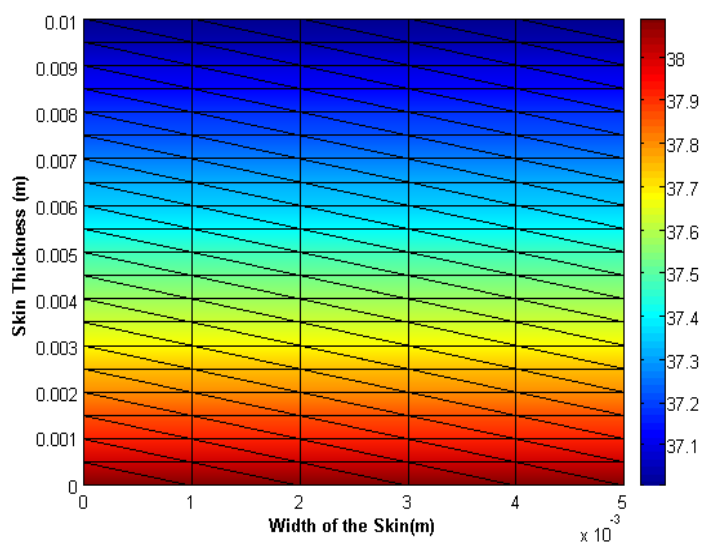

Figure 23: Temperature distribution of females skin layers at mesh of size 200 elements for sweating effect analysis. 
Citation: Gurung DB, Acharya S (2018) Sweating Effect on Males and Females Body Temperature Variation. J Appl Computat Math 7: 401. doi: 10.4172/2168-9679.1000401

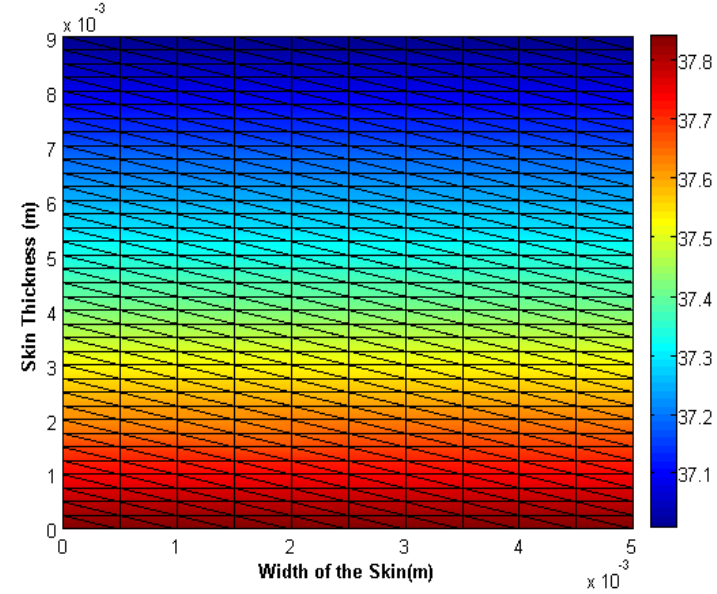

Figure 24: Temperature distribution of males skin layers at mesh of size 720 elements for sweating effect analysis.

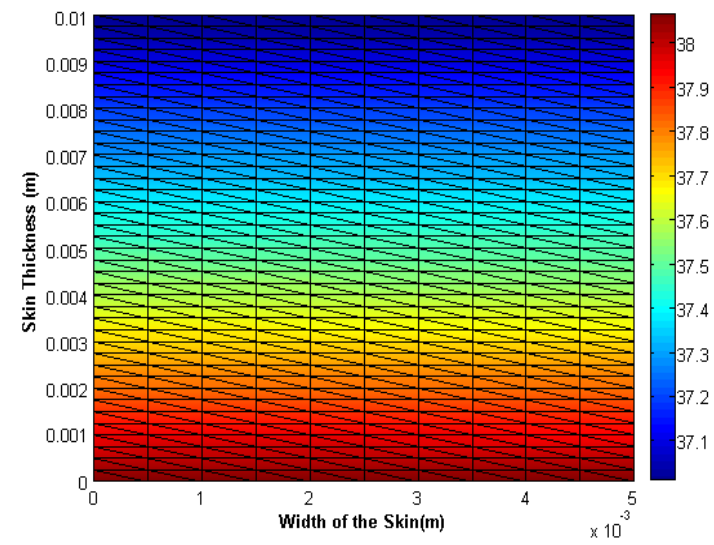

Figure 25: Temperature distribution of females skin layers at mesh of size 800 elements for sweating effect analysis.

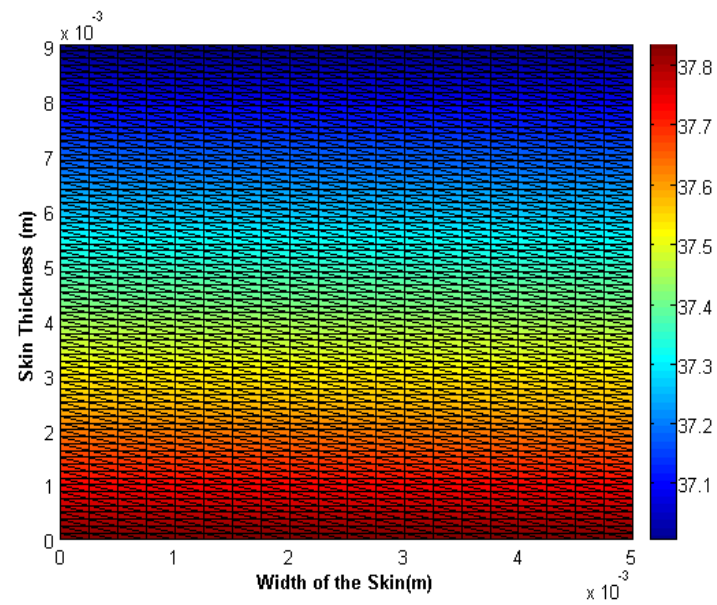

Figure 26: Temperature distribution of males skin layers at mesh of size 2880 elements for sweating effect analysis.

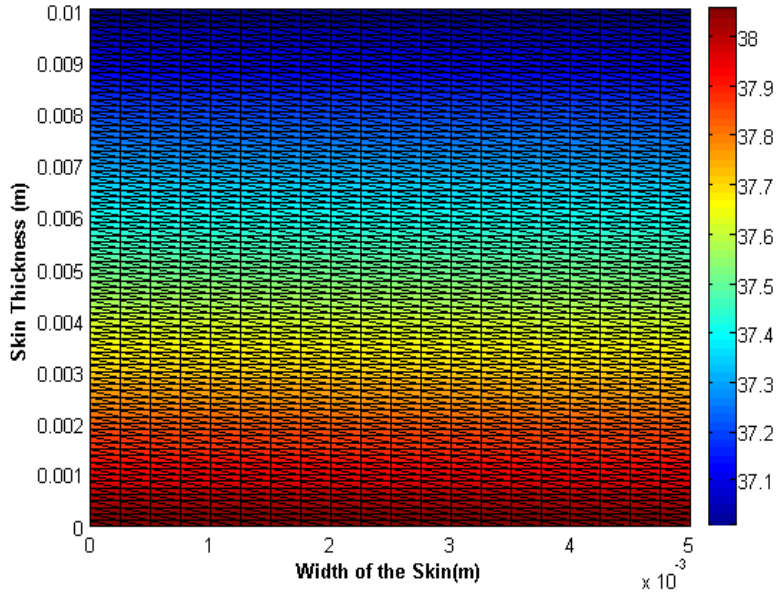

Figure 27: Temperature distribution of females skin layers at mesh of size 3200 elements for sweating effect analysis.

\begin{tabular}{|c|c|c|}
\hline Nodes & Mesh size & Temperature values \\
\hline 114 & 180 & $37: 86^{\circ} \mathrm{C}$ \\
\hline 407 & 720 & $37: 83^{\circ} \mathrm{C}$ \\
\hline 1533 & 2880 & $37: 83^{\circ} \mathrm{C}$ \\
\hline
\end{tabular}

Table 9: Convergence study in two dimensional temperature variation of TSC of males for sweating effect analysis.

\begin{tabular}{|c|c|c|}
\hline Nodes & Mesh size & Temperature values \\
\hline 126 & 200 & $38: 09^{\circ} \mathrm{C}$ \\
\hline 451 & 800 & $38: 06^{\circ} \mathrm{C}$ \\
\hline 1701 & 3200 & $38: 06^{\circ} \mathrm{C}$ \\
\hline
\end{tabular}

Table 10: Convergence study in two dimensional temperature variation of TSC of females for sweating effect analysis.

\section{Conclusion}

We have simulated and analysed one and two dimensional comparative steady state and transient temperature differences in males and females sweating effect. The analysis sought out that tissue temperature in males is slightly higher as compared to female when atmospheric temperature $T_{\infty}$ is less than body core temperature. But the females tissue temperature is higher when $\mathrm{T}_{\infty}$ exceeds above $37^{\circ} \mathrm{C}$ The steady state nodal temperature is achieved earlier in case of males in comparison to females.

Though sweating is important for maintaining proper temperature and keep us from overheating in our body, but our results show that when atmospheric temperature $\mathrm{T}_{\infty}$ is greater than or equal to $45^{\circ} \mathrm{C}$ interface tissue temperature is greater than $37^{\circ} \mathrm{C}$. So sweating mechanism is not the only cause to keep the body core temperature at normal level. We thus have to follow the precautions such as using fans, stay inside the home or air cooler system, drink plenty of cold water, and wear white cotton clothes etc., while surrounding temperature is too hot.

\section{References}

1. Acharya S, Gurung DB, Saxena VP (2012) Time dependent temperature distribution model in layered human dermal part. Journal of Science, Engineering and Technology 8: 66-76.

2. Kingma B, Frijns A, Van Marken Lichtenbelt W (2012) The thermo neutral zone: implications for metabolic studies. Front Biosci 4 :1975-1985.

3. Nadel ER, Bullard RW, Stolwijk JA (1979) Importance of skin temperature in the regulation of sweating. J Appl Physiol 31: 430-437. 
Citation: Gurung DB, Acharya S (2018) Sweating Effect on Males and Females Body Temperature Variation. J Appl Computat Math 7: 401. doi: $10.4172 / 2168-9679.1000401$

Page 11 of 11

4. Wyndham CH, Morrison JF, Williams CG (1965) Heat reaction of male and female caucasians. J Appl Physiol 20:357-364.

5. Gurung DB, Saxena VP (2010) Peripheral temperature distribution in human subjects exposed to wind ow. International Journals of Mathematics and Engineering 73:728-740.

6. Gurung DB, Saxena VP, Adhikary PR (2009) Fem approach to one dimensional unsteady state temperature distribution in the dermal parts with quadratic shape function. J Appl Math Informatics 27: 301-313.

7. Gokul KC, Gurung DB, Adhikary PR (2015) Mathematical model: comparative study of thermal effect of laser in corneal refractive surgeries. Application and Applied Mathematics 10: 609-619.

8. Goldman RF (1998) Standards for human exposure to heat. Environmental Ergonornics 1998.

9. Gurung DB (2012) Two dimensional temperature distribution model in human der-mal region exposed at low ambient temperature with air flow. Journal of Science, Engineering and Technology 8: 11-24.

10. Guyton C, Hall E (2009) Text book of medical physiology, second edition Elsevier.

11. Jankowska AM, Sypniewska-Kaminska G (2012) An interval infinite difference method for the bioheat transfer problem described by the pennes equation with uncertain parameters. Mechanical and Control 31: 77-84.

12. Khanday MA, Aijaz M, Nazir K, Rafiq A., Hussain F et.al (2015) Finite element approach to study the behavior of uid distribution in the dermal regions of human body due to thermal stress. Journal of Egyption Mathematics Society 23: $568-574$

13. Odland GF (1991) Structure of the skin. Physiology, biochemistry and molecular biology of the skin. third edition Oxford University Press 1:3-62.

14. Pardasani KR, Jas $P$ (2000) Numerical simulation of the effect of polycythemia vera on heat flow in human dermal region. Indian J Pure Ap Mat 31: 1595-1606.

15. Pennes HH (1998) Analysis of tissue and arterial blood temperatures in the resting human forearm. J Appl Physiol 85: 5-34.

16. Reedy JN (2010) An introduction to the infinite element method. Third edition.

17. Acharya S, Gurung DB , Saxena VP (2013) Effect of metabolic reactions on thermoregulation in human males and females body. Appl Math Comput 4:39-48.

18. (2016) Mathematical modelling of sex related differences in the sensitivity of the sweating heat responses to change in body temperature, British Journal of Applied Mathematics and Computer Science, Science Domain International 12:1-11.

19. Acharya S, Gurung DB, Saxena VP (2014) Human males and females body thermoregulation: perfusion effect analysis. Journal of Thermal Biology 45 30-36.

20. Acharya S , Gurung DB, Saxena VP (2015)Two dimensional infinite element method for metabolic effect in thermoregulation on human males and females skin layers, Journal of Coastal Life Medicine 3: 930-936.

21. Wenger CB (1996) Human responses to thermal stress, technical note no tn96-3, usariem, Environmental ergonornics. 